The Critical Success Factors of Business Growth among Women Entrepreneurs in Malaysia: A Qualitative Approach

Normilia Abd Wahid, Nurul Nadia Abd Aziz, Maisarah Ishak, Adibah Hussin

To Link this Article: http://dx.doi.org/10.6007/IJARBSS/v11-i9/10861 DOI:10.6007/IJARBSS/v11-i9/10861

Received: 06 July 2021, Revised: 10 August 2021, Accepted: 29 August 2021

Published Online: 27 September 2021

In-Text Citation: (Wahid et al., 2021)

To Cite this Article: Wahid, N. A., Aziz, N. N. A., Ishak, M., \& Hussin, A. (2021). The Critical Success Factors of Business Growth among Women Entrepreneurs in Malaysia: A Qualitative Approach. International Journal of Academic Research in Business and Social Sciences, 11(9), 1445-1459.

Copyright: @ 2021 The Author(s)

Published by Human Resource Management Academic Research Society (www.hrmars.com) This article is published under the Creative Commons Attribution (CC BY 4.0) license. Anyone may reproduce, distribute, translate and create derivative works of this article (for both commercial and non-commercial purposes), subject to full attribution to the original publication and authors. The full terms of this license may be seen at: http://creativecommons.org/licences/by/4.0/legalcode

Vol. 11, No. 9, 2021, Pg. 1445 - 1459

Full Terms \& Conditions of access and use can be found at http://hrmars.com/index.php/pages/detail/publication-ethics 


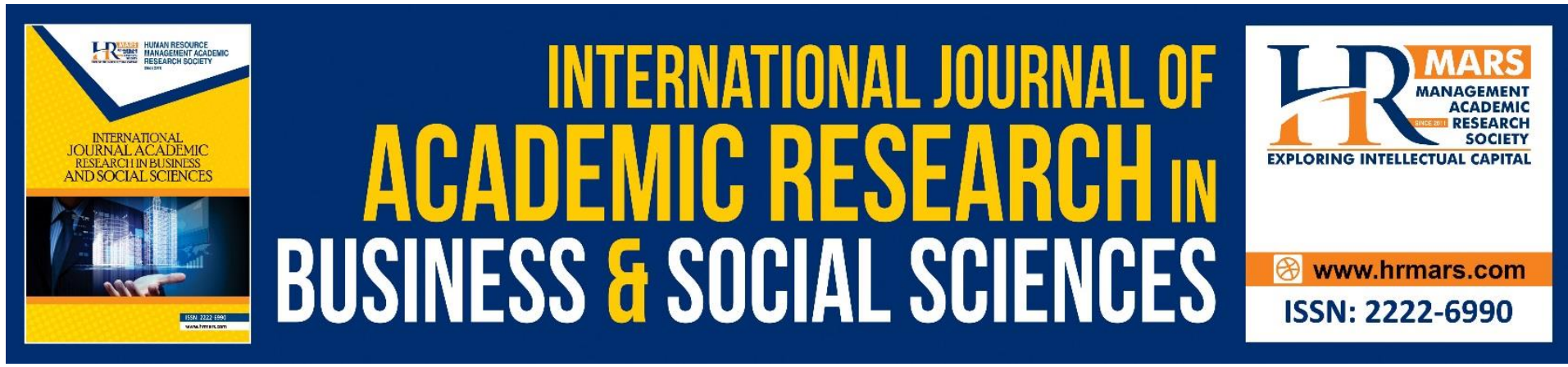

\title{
The Critical Success Factors of Business Growth among Women Entrepreneurs in Malaysia: A Qualitative Approach
}

\author{
Normilia Abd Wahid ${ }^{1}$, Nurul Nadia Abd Aziz², Maisarah Ishak ${ }^{3}$, \\ Adibah Hussin ${ }^{4}$ \\ 1,3,4 Faculty of Business and Management, Universiti Teknologi MARA Pahang \\ (Jengka Campus), Jengka, Pahang, Malaysia, ${ }^{2}$ Faculty of Business and Management, \\ Universiti Teknologi MARA Pahang, (Raub Campus), Jengka, Pahang, Malaysia
}

\begin{abstract}
This article examines the critical success factors of business growth among women entrepreneurs. In Malaysia, women have been given significant contributions to their participation in entrepreneurship activities. However, the economic potentials of woman entrepreneurs remain to be tapped. Hence, it is important to identify what are the factors that contribute to the slow business growth pattern to assist them to grow better. This study adopts purposive and snowball sampling. Several criteria that were considered include first, the samples must be well-educated women holding at least a diploma certificate, second, they are married and third, they are involved in any kind of business. The data and information collected will be thematically analysed using the ATLAS.ti software. The result showed that the first place of critical success factors of business growth among women entrepreneurs in Malaysia is contributed by limited access to financial resources followed by unskilful workers, imbalance family and business responsibilities, and lack of training. This study is conducted on women entrepreneurs in a selected state of Malaysia. Since this study applied a qualitative approach, the limitations include the results may not be representative of all women entrepreneurs. Hence, the conclusion is not generalisable. The finding from this study, therefore, demonstrated that empowering women entrepreneurs require effective cooperation from all parties including the government and other agencies to ensure the inclusiveness of all entrepreneurs. These assistances may be in terms of capital or finance, business advice, education, and training programmes.
\end{abstract}

Keywords: Critical Success Factors, Business Growth, Women Entrepreneurs

\section{Introduction}

In Malaysia, women have been given significant contributions to their participation in entrepreneurship activities. In 2016, 20.6\% of SMEs were women-owned from a total of 98.5\% of SMEs business establishments in Malaysia. These SMEs owned by women entrepreneurs have influenced SMEs Gross Domestic Product (GDP) contribution to increase steadily to $36.6 \%$ compared to $36.3 \%$ that was recorded in 2015 (Department of Statistic 
Malaysia, 2016). These data showed that the Malaysian government has taken severe actions in supporting and encouraging the growth of woman entrepreneurs.

To strengthen women empowerment in Malaysia, particularly in the economic aspect, the government has also launched Women's Empowerment Year 2018 to see how women can play a greater role in economic activities. Global has also recognised the importance of promoting women entrepreneurship to more significant levels. There is no reason to neglect the talents and the capabilities of women, but they need the support system that will help them to fully utilise their potentials.

The number of educated women to a degree level and above have increased internationally. According to the Female Labour Participation Rate (FLPR) in 2016, the rate is $54.3 \%$ and it has been mentioned that for every 100 women, 54 were in the labour force (Department of Statistic Malaysia, 2016). However, only $18.3 \%$ were involved in the professional market. These data indicated that there are many highly educated and professional women out there, but they do not enter the labour market. Many of them are involved in entrepreneurship as an opportunity to gain additional income while some of them quit their job and start a career as entrepreneurs (Mohamad \& Bakar, 2017). This shows that Malaysia has many educated and professional women that are equipped with knowledge and skills to strengthen their potential to up-level their businesses. While the numbers portray the growth rate of women in establishing businesses, the economic potentials of woman entrepreneurs remain to be tapped. Despite many of them are successful businesswomen, most of them own small companies to serve their local markets and do not operate internationally. According to Rashid, Che Ngah, Mohamed, and Mansor (2015), studies have shown that although most women entrepreneurs enjoying their high income from their businesses, it is not reflected in the GDP calculation since the income is not reported or under-reported. Another study reported that some women entrepreneurs omitted to expand their businesses despite been given funding and initiatives supported by the government and other related agencies for many years (Bernama, 2014).

Generally, woman entrepreneurs rely heavily on internal sources compared to external sources of capital to start up. They have less external financing, thus limiting their entrepreneurship activities (OECD, 2017). Besides that, survival rates for female-owned businesses are typically low, which may cause economic barriers such as more restrictive capital financing, as well as stereotypes in which company generally involved by the woman entrepreneurs (OECD, 2017). In another aspect, entrepreneurial orientation has influenced the business performance of woman entrepreneurs (Hassan, Ramli \& Mat Desa, 2014; Mahmood \& Hanafi, 2013), but due to lack of experience, exposure, business skills, and knowledge have refrained them to successfully run their businesses (Mohamad \& Bakar, 2017). Referring to Abdul Mutalib et al (2015) study, many programmes focusing on woman entrepreneurship in Malaysia are still limited and should be given more initiative to empower women by providing various alternative entrepreneurship programmes that suit women entrepreneurs' backgrounds. Moreover, it is crucial to expose women to international business ventures in order to expose them forward in the business world (Hashim, Yaakob \& Muhayiddin, 2015).

Studies have reported that the possible reasons ranging from problems of accessing international markets, lacking access to financing, obsolete technology, lack of innovation, and inability to establish business networks (Musa et al., 2016; Hashim, et al., 2015; Loveline, Uchenna \& Karubi, 2014; Hassan, \& Mugambi, 2013) have resulted in a market failure that prevents them from achieving their full potentials as successful entrepreneurs. 
The factors that influenced the success of women entrepreneurs are social environment, specifically networking, financial resources, and entrepreneurial skills (Hassan et al., 2013; Tundui \& Tundui, 2012). However, in Malaysia, only a few studies have discussed the successful Malaysian woman entrepreneurs in general. Therefore, this study aims to identify the critical determinants of the growth of women entrepreneurs in Malaysia by focusing mainly on highly educated women entrepreneurs and the government intervention to develop a support system to allow women entrepreneurs to scale up and to take it to the next level, internationally.

This study also investigates the critical determinants of growth, particularly for highly educated and professional woman entrepreneurs in Malaysia. Therefore, this study will adopt a qualitative approach that involves semi-structured interviews to yield 'thick' and detailed data. This method is considered appropriate in gaining an understanding of how their educational background may affect them to involve in business, and what is their goal of doing business. This study adopts purposive and snowball sampling with three criteria that include the women entrepreneurs must be well-educated women holding at least a diploma certificate, married, and are involved in any kind of business. The data and information collected will be thematically analysed using the ATLAS.ti software.

The findings of this study are expected to contribute to the regulators and government agencies in designing appropriate responses to the market failures to support firm growth, internationally. Furthermore, this study will provide useful information to the policymakers on the support system needed by women entrepreneurs in Malaysia. It will help to strengthen the empowerment of highly qualified women in socio-economic benefits.

\section{Literature Review}

In Malaysia, the entrepreneur is commonly known as a small-scale business that is based at home. However, the real definition of an entrepreneur is an individual who is willing to put efforts to bundle resources in innovative ways and is ready to bear the risk from his/her action (Hishrich, Peter \& Sherpherd, 2013). A woman entrepreneur generally can be defined as a woman or a group of women, who initiates, organise, and operate a business enterprise and is willing to accept any risk (Maliani \& Shukri, 2017). Looking at the trend of woman entrepreneurs in Malaysia, the development is quite impressive. However, the gap between gender in entrepreneurship still exists, and only a small portion of women entrepreneurs have established and formed their name in the local or international market. Therefore, this chapter will discuss the issues and challenges that may be faced by woman entrepreneurs.

\section{The Critical Success Factors of Business Growth}

\section{An imbalance between Family and Business Responsibilities}

The main challenges that are typically faced by these woman entrepreneurs are balancing their_responsibilities between family and business. Some people start their own business to have enough time with their families. Some of them quit their current job and set up their own business that is based at home in the hope to spend time with their children while generating income for their families. However, little that they know a women entrepreneur must balance her time between family and business. According to Borg (2013), 44\% of woman entrepreneurs agreed that responsibility as a mother influenced their decision to start a business in which they have to hold their plan of opening a business until when the children are older. The worst part is that some of these woman entrepreneurs had to permanently close their business in the middle of the journey because they were afraid that they might be 
unable to balance the commitment of family and business. In addition, some of them are not given support and motivation by their spouses to move forward in the business. The husband felt and believed that his wife would have less time and focus for the family if they are involved in the business (Tarmizi, Rozana \& Hairazi, 2016). Therefore, these woman entrepreneurs found difficulties in balancing their family responsibilities and their business obligations. This is a common scenario especially when they have to work at odd hours to fulfil the demand from their customers and taking care of family matters at the same time (Mazlina \& Punitha, 2016).

\section{Access to Finance}

The other problems that may arise are access to finance. In a business cycle, the need for finance is a continuous necessity. The entrepreneur may need it upon the start-up of the business or during early growth or maybe during full growth and expansion. According to Hajwa et al., (2017) study conducted in Daerah Hulu Langat, the financial resource has the strongest relationship with the success of a business. This report was supported by Ayob, Daud \& Ismail.(2016) in which respondents in their interview pointed that financial assistance is a significant factor in the performance of women entrepreneurs. However, the challenging part is to secure financial aid from the bank or any other organisation. In a study done by Mazlina and Punitha (2016), 7 entrepreneurs from a total of 10 encounter problems in getting loans to start their business. The failure occurs maybe because they cannot provide collateral and due to the non-existence of track records. Galli and Stefania (2015) found that woman entrepreneurs face a higher rate of rejection in loan applications compared to men. The woman entrepreneurs have some difficulties in accessing financial facilities. Besides that, their applications for financial facilities are less than man entrepreneurs because of fear of rejection by the loan provider. Due to this, most woman entrepreneurs prefer to use their saving to set up a business, and this can be a constraint for them to expand their business further.

\section{Knowledge and Skill}

It is also found that woman entrepreneurs faced problems related to their knowledge and skills in business. According to Bharthvajan (2014); Thuaibah et al (2007); Noraini (2005) lack of sales and marketing skills were the common problems reported among women entrepreneurs that can be a hindrance to the growth of their business. Women entrepreneurs need to sharpen their sales and marketing skills so that they can ensure continuous customer to support their business. Besides that, knowledge of information technology has also become a challenge for women entrepreneurs in developing their businesses (Bharthvajan, 2014). It is essential for women entrepreneurs to be literate in technology-based tools because it is increasingly accessible for customers. However, Samina (2015) in her research among woman-owned businesses argued that woman entrepreneurs need to be assisted by an influential advisor who understands technology and are an expert in business processes. They need to understand several types of technology that are required by their business to be improved. Chatterjee, Gupta, and Upadhyay (2020) agreed that information and communication technology are important for women empowerment, particularly for business development. 


\section{Unskilful Workers}

Skilful workers are important for business upliftment. However, most start-up entrepreneurs are unable to employ skilful workers. Most women entrepreneurs are getting help from unskilled workers and this makes the business is suffering from low managerial capabilities. Bonazza, Ardjouman, and Abada (2015) revealed that lack of skilled workers contributes as a major constraint for unstable and limited growth of SMEs in most developing countries. According to Lahiri (2012), only large firms can employ skilled workers with higher remuneration.

\section{Training}

Training programmes are also significant in contributing to the success of women entrepreneurs. Several programmes should be widely introduced and implemented by the government, private sectors or non-government organisations as a measure to encourage and assist woman entrepreneurs in developing and sustaining their entrepreneurial knowledge and skills. According to Mutalib, Arshad, Ismail, and Ahmad (2015), in their research of identifying entrepreneurship programmes for women entrepreneurs, these programmes can be specifically organised based on the need of these women that include technology-related activities, business knowledge and skills, and operation of a business.

\section{Methodology}

As the ultimate aim of this research is to obtain rich and detailed data that will lead to a greater level of understanding of the antecedents and factors that hinder educated women not to expand their business, and to generate insights into issues that might exist, it is considered beneficial that the data should be obtained within an individual domestic unit. Given the purpose of the study, it is not necessary to seek representatives across the whole population. Therefore, the researchers selected a group that is sufficiently varied in nature to generate data on a range of pragmatic features. Due to time and resource constraints, it will be considered that this might be best viewed as an exploratory study that could lead to more wide-ranging research in the future. Therefore, this study will adopt a qualitative approach that involves semi-structured interviews in yielding 'thick' and detailed data. This method will be assumed as appropriate in gaining an understanding of how their educational background may affect them to involve in business, and what is their real goal of doing business.

The participants for this research were chosen based on the purposive and snowball sampling method. A purposive sample of 15 women entrepreneurs was recruited. Using purposive sampling, we use our judgment to select a sample that we believe will provide the data that we need. The inclusion criteria of the participants were (1) the samples must be welleducated women holding at least a diploma certificate, (2) they are married, and (3) they are involved in any kind of business.

We recruited and interviewed participants concurrently until the data were saturated whereby no new data were obtained from further interviews. The sociodemographic characteristics of the women entrepreneurs such as age, education status, location of the business, and the types of industry involved were obtained before the interview. Each interview lasted for 40 to 60 minutes.

The recorded interviews were transcribed verbatim. All interviews were conducted in the Malay language, which was translated to the English language by the researcher who conducted the interview. The transcript was then reviewed by another researcher to assess the accuracy of the translation by the first researcher. The data and information collected 
were thematically analysed using the ATLAS.ti software. Four themes emerged from the findings that are (1) limited access to financial resources, (2) unskilful workers, (3) an imbalance between family and business responsibilities, (4) knowledge and skills, and (5) lack of training.

Table 1: Profile of the participants

\begin{tabular}{|l|l|l|l|l|l|}
\hline No & Name & Age & Location & Industry & $\begin{array}{l}\text { Level } \\
\text { education }\end{array}$ \\
\hline 1 & Ekin & 38 & Maran Pahang & Food & Diploma \\
\hline 2 & Wirda & 45 & Maran Pahang & Clothing & Master \\
\hline 3 & Nurul & 39 & Bangi Selangor & Food & Degree \\
\hline 4 & Aini & 39 & Putrajaya Selangor & $\begin{array}{l}\text { Maternity and } \\
\text { Baby stuff }\end{array}$ & Degree \\
\hline 5 & Lily & 39 & Sg Petani Kedah & Bakery & Degree \\
\hline 6 & Elle & 27 & Penang Pulau Pinang & Photography & Diploma \\
\hline 7 & Milah & 40 & Bangi Selangor & Food & Degree \\
\hline 8 & Badariah & 39 & Temerloh Pahang & Skincare & Diploma \\
\hline 9 & Salimah & 35 & Kota Bharu Kelantan & Healthcare & Master \\
\hline 10 & Mar & 34 & Klang Selangor & Healthcare & Master \\
\hline 11 & Fatin & 25 & Kuala Lumpur & Skincare & Diploma \\
\hline 12 & Najwa & 25 & Kuala Lumpur & Skincare & Diploma \\
\hline 13 & Rinie & 40 & Johor Bharu & Insurances & Degree \\
\hline 14 & Zura & 39 & Johor Bharu & Food & Degree \\
\hline 15 & Has & 42 & Kedah & $\begin{array}{l}\text { Education } \\
\text { (Nursery) }\end{array}$ & Degree \\
\hline
\end{tabular}

\section{Results and Discussion}

This part contains an analysis of the demographic factors of the respondents include age, education level, duration of business, and type of business. It also comprises analysis of the data gathered during the interviews in the fieldwork based on the limitations faced by the respondents that affect the growth and development of their businesses.

A total of 15 Malay women entrepreneurs were recruited as respondents. The age of the respondents ranging between $25-45$ years old. They are chosen from various industries such as bakery products, photography services, clothes boutiques, maternity and baby staff, and traditional desserts. The duration of the business in the market is between 3 to 15 years. However, their academic qualifications are the main priority to align with the objective of this study to investigate the critical determinants of growth, particularly for highly educated and professional woman entrepreneurs in Malaysia.

\section{Challenges and the Impact on Business Growth Limited Access of Financial Resources}

Limited access to financial resources was the main barrier faced by the respondents. Most of the respondents (40\%) reported that the most significant obstacle that they are facing for business growth is lacking financial resources. Even most of them are already 10 years in the market, but they are remained tapped. The following issues were gathered and make us understand how these barriers affecting the respondents' businesses: 
Ekin, 35 years old and diploma holder who owns a restaurant explained why limited access to financial resources is a huge barrier for her business growth. She said that;

"One of the most significant barriers I facing to grow my business is the inability to access financial support from the financial provider because of bureaucracy matters. I felt the information given was scattered, and it was hard for me to get a good overview of what was available to me as an owner. They sometimes dealing with customers more complex systems means they failed to manage things quickly and efficiently".

Also, this comment is supported by another respondent. Wirda, 45 years old degree holder who owns a clothes boutique stated that the substantial capital is a primary reason why she delayed extending her business growth. She stated that;

"I took more than ten years to build my boutique as I have today. I have a familiar brand name in my business area. However, my business does not grow as much as it is supposed to because of lacking financial resources. Usually, the problem arises when I can't' manage my credit purchase from suppliers. It becomes worse when suppliers are not allowed to make a credit purchase. So, I had to buy in a cash payment. The issue is when you come to the financial provider, especially financial institutions, to make a loan or to support financial resources, the terms and conditions stated are not meet. They only accept that company with strong cash flow".

Another respondent, Nurul (39 years old and a degree holder) who owns a home-based business making a variety of traditional desserts mentioned that one of the most significant barriers to growth is financial resources. According to her;

"I have a mission to make sure my business grows in the next two years as I already develop my business for almost three years. My vision is to open a central kitchen and kiosk or outlet in a few strategic locations and hire skilled workers. Yet, it is still an unclear way to plan because for now, the situations do not allow due to the outbreak of the pandemic covid-19. However, my most significant barrier is a deficient of financial resources. For now, I can manage my business with my saving. The daily sales keep my business secure as the available cash is rolling the capital. Nevertheless, it is just enough to accommodate my daily operation. For business growth, I need support from a financial provider, especially with zero interest. I do not want to commit to payback with the volatile economic situation. So, I really hope the financial provider will offer a good plan for financial loans to a home-based business".

Limited access to financial resources is the main reason stated by the rest of the respondents that declared as the most challenging factor that hinders their businesses growth although they have been long in the market. The financial constraint also causes struggles and demotivation among women entrepreneurs to achieve their mission. Our findings are in line with the study of previous researchers (Galli \& Stefania, 2015; Ayub et al., 2016) who also found that financial assistance is a significant factor in the performance of women 
entrepreneurs. Furthermore, Mazlina and Punitha's study (2016) also supports our findings in which they claimed that $70 \%$ of their respondents also had problems in obtaining loans from commercial banks. Kumbhar's (2012) study explains that women entrepreneurs in India have difficulty in getting financial support due to the banks and financial institutions are not willing to give credit to them because of their credibility problem. In short, the type of financial aid received by women entrepreneurs will influence their motivation and barriers in growing their business (Akehurst, Simarro, \& Mas-Tur, 2012).

\section{Unskilful Workers}

The second challenge for women entrepreneurs is the difficulty of getting skilled workers. A total of $20 \%$ of our respondents indicated that the inability to hire skilled workers has slowed down the development of their business. There is an opportunity to gain more sales and dominate market shares in their business area. Yet, there are not enough skilled workers to help them to utilise that opportunity. The detailed explanations of this problem are as follows: Elle (25 years old and a diploma holder) who owns a home-based business photography service explained that it is essential to have skilled workers to deliver excellent service to the customers. She said;

"My line of business requires me to employ skilled workers that can provide customers with fast and efficient services. This always happens during a peak season like special events or occasions that need extra attention to give the highest satisfaction to the customers. Importantly for a small business like me, I need to make sure that my service offer is consistently in good service. Usually, most skilled workers prefer to work for an established company that can afford to pay them high salaries. Sometimes in a particular situation, I have no other option but need to pay them with a reasonable cost to meet their skill. This situation has been reducing my profits as well".

Another respondent, Lily, 39 years old and a degree holder who also owns a home-based business as a baker stated that it is essential to have skilful workers, especially those are expert in baking. She said;

"Bakery products are used daily and are liked by all. So that the demand is always there, I need extra workers that having excellent knowledge and skills that the pastry chef must possess. It is because baking skills need creativity and patient to give the best products. Also, to become the best baker, they need to keep learning, and based on my experience most of the newest bakers, their priorities are only for money. For that reason, I need to pay the highest cost for a skilled worker to ensure my product quality is in order".

The above explanations show that indeed there are difficulties in obtaining skilled workers, which is the cause of stunted business development. These findings are in line with the study from Bahramitash and Esfahani (2014) who found that women entrepreneurs in Iran are having problems in finding skilled workers. According to Matt Welch (2021), small business owners reported to unable to fill in the job openings due to the lack of qualified workers. Some business owners offered high salaries or on-the-job training to attract talent, however, some business owners do not take such measures to save money. 


\section{An Imbalance between Family and Business Responsibilities}

The result from this study also showed that another $20 \%$ of the respondents are facing difficulty in establishing a balance in their responsibilities towards family and business obligations. They have some substantial factors in moving forward in business such as strong capital and skill but lacking motivation in terms of family matters. The following are experiences shared by the respondents:

Aini, 39 years old and a degree holder who owns a home-based business in producing maternity and baby products stated that the main reason why it is difficult to extend her business activities is because of her role as a wife and mum to 7 kids. According to her;

"I took many times to think to leave my kids to the nursery. Many issues like child abuse and kidnapping make me need to take extra precautions before deciding to move forward in my business. However, my mission is still in planning for expanding my business by collaborating with establishing maternity and baby boutiques. Yes, I agreed that to balance both obligations, family and business at the same time is very difficult because you aim a big mission for both".

Mila, 39 years old and a degree holder also give the same reason whereby to balance her responsibilities for family and business has blocked her intention to grow her business. She owns a home-based business making traditional dishes. Even though she has an opportunity to expand the market, but there are still obstacles to grab. She mentioned;

"I look forward to my business, but for the time being my family is the main reason why I am just focused on remaining constant. I find it difficult to balance my family and business obligations because sometimes I felt too much to handle both".

The results of these interviews show that not only women working in the government and the private sector experiencing work-family conflict, but the same situation was also experienced by women entrepreneurs. A study by Hassan, Dollard, and Winefield (2010) found that Malaysians reported higher FIW than Westerners, whereby FIW was seen to negatively affect job, family, community, and life satisfaction. In other words, our respondents are very concerned about work-family balance, hence work-family conflict has to be avoided. Thus, a more supportive work-family culture and flexible work arrangements (Masuda, Sortheix, Beham \& Naidoo, 2019) has to be made to lead achievement in life purposes, which is a balance between work and family roles.

\section{Knowledge and Skills}

In addition, $10 \%$ of the respondents agreed that knowledge and skill play an important factor to survive in business since entrepreneurs need to constantly adapt strategies to capitalise on the current trends. Therefore, it is essential to keep learning and upgrading entrepreneurial knowledge and skill.

Has, 43 years old and a degree holder who owns a kindergarten said that knowledge and skill must be continuously upgraded to enhance and adapt to the current demand. She said;

"The trend of technology is very fast-changing. So for me, that is in the educational industry for almost 10 years, it is a need starting at the early stage level to introduce the new technology in the kindergarten classroom. It is essential for giving early learners a good introduction to these new skills. Thus, we're as an educator must possess new teaching style and expands our abilities to fulfil the current need. However, we need more short-term courses that provided appropriate knowledge and skills offered by related agencies to enhance our 
abilities in serving good quality of teaching. The issue here is the costs incur will jeopardize our daily expenses. Somehow, the courses offer are quite expensive and we are unable to be liable for the costs. In the end, we are incapable to give all the staff the needed courses, then will turn slow business performance compared to others".

The same view is given by a number of respondents that agreed that the current knowledge and skill are important in the business development and survival in which small enterprises are struggling to insert themselves in the competitive market. According to Al Mamun, Fazal, and Muniady (2019), entrepreneurial skills have a positive effect on entrepreneurial competency and enterprise performance. Therefore, women entrepreneurs must adopt new knowledge and skill to accommodate the current demands.

\section{Lack of Training}

Moreover, another $10 \%$ of the respondents confirmed that they should have extra training and support to develop the core skills and competencies they need to be successful in entrepreneurial activity. Khaleque, (2018) reported that the lack of training opportunities is impeding the process of business development. Most of them experiencing a lack of time to upgrade their skills because of the difficulties in balancing their time when working at home (Bhardwaj, 2014). Most of them inherited the skills from their family members, and this is not a strong trait to accommodate the current demand. Therefore, they highly need opportunities to participate in courses that offer flexibility in terms of time and place.

Thus, these results confirm that this study has achieved the research objective by identified five critical determinants of the growth of women entrepreneurs in Malaysia as arranged according to the most critical factors. Following is a summary of determining factors faced by the respondents to grow in their businesses. First place is contributed by limited access to financial resources (40\%) followed by unskilful workers (20\%) and a similar result for imbalance family and business responsibilities (20\%). Knowledge and skills share the same result with training factor with $10 \%$ each.

Table 1: Summary of determining limitation factors for growth faced by the respondents

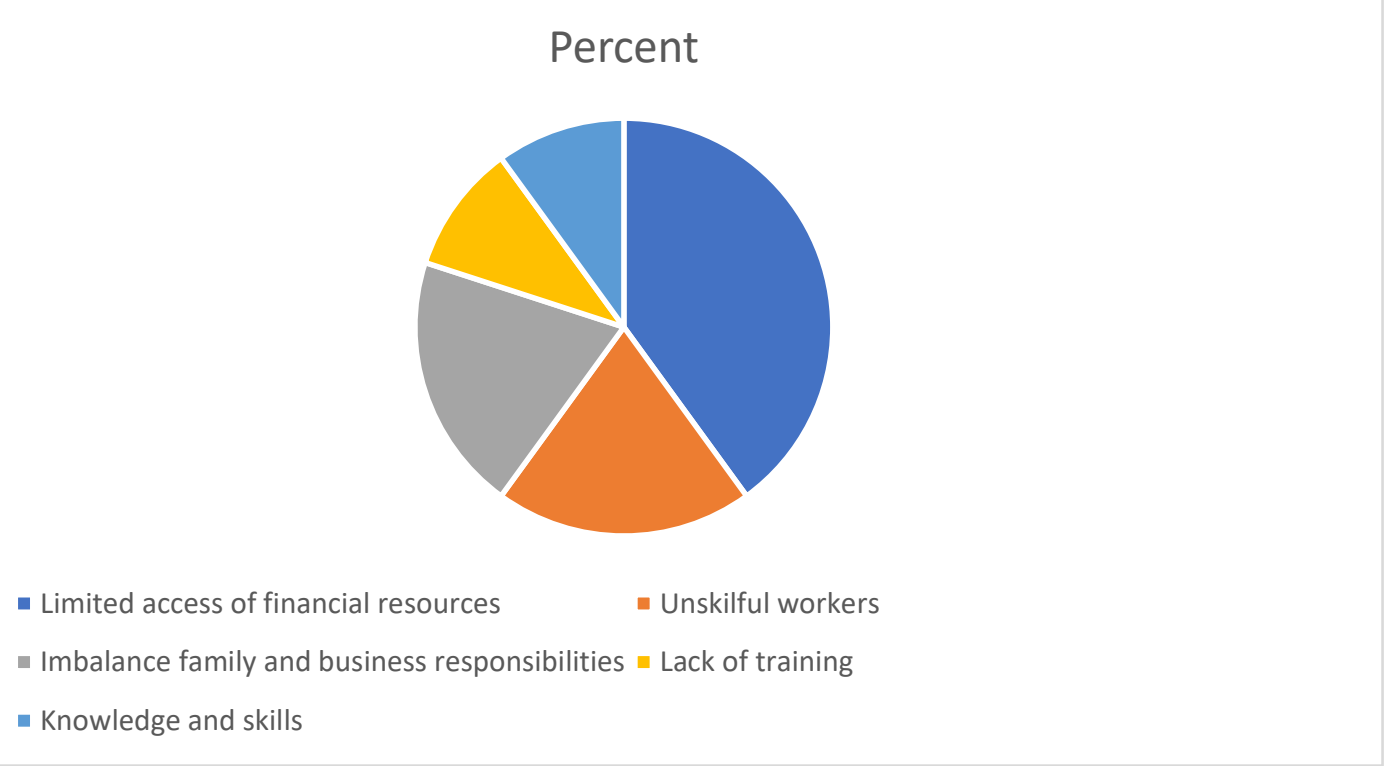




\section{Conclusion and Recommendation}

It is suggested that women entrepreneurs use technology in facing the challenge of financial resources. By using technology or online tools, they can reduce the costs, especially in marketing activities such as develop a website and using social media to promote their products. The use of Instagram, Facebook, Youtube, Whatsapp, and other digital channels can help women entrepreneur to prove and convince potential customers of the advantages of their products. They can share pictures, videos, and interactive media of the products to create high-quality content that can allow acquiring new customers.

Digital marketing is cost-effective for a business compared to the traditional forms of marketing that involved the cost of printing, billboards, radio and television advertisements. According to Rahman, Yaacob and Mat Radzi (2016), digital marketing can help women entrepreneurs to connect with more customers globally, encourage active interaction, and provide an immediate response to the customer at a lower cost. Thus, this method of marketing is very effective for all types of customers, especially younger customers or the millennial generation who are spending more time on their mobile devices.

Equipping the employee with the skills required for the current job is one of the key factors for business development and growth. Businesses become more competitive with having a knowledgeable employee that plays their roles in completing their job. Therefore, a training programme is crucial for the employee to enhance their skills and improve knowledge to become more effective in the workplace. Based on the findings, women entrepreneur needs to improve themselves by attending online training that can give more advantages including affordability, flexibility, and accessibility. Online training can encourage women entrepreneurs to join the training session at anytime and anywhere to improve their capabilities for the success of their business.

Moreover, this training method ensures flexibility, is cost-effective and involved knowledge sharing and transfer globally. Trainee only need to have an Internet connection to attend the training session and it is not only restricted to the desktop, but the training courses are available in many types of devices and mediums. They can learn various business skills from different training courses conducted by a professional trainer that always looking to help and motivate the trainee.

Next, to become successful entrepreneurs they need networking to allow them to access the opportunities, information on the potential supplier, support agencies, and others. On the other hand, a network also opens your opportunity to meet people who are in similar circumstances. Therefore, you may exchange ideas, information, experience, and business contacts. Most entrepreneurs are optimistic and positive. Meeting them may help to encourage and motivate women entrepreneurs especially when they are in difficulties or early phase of business.

In Malaysia, the affairs of women are currently under the purview of the Ministry of Women, Family and Community Development (MWFCD). Many programmes have been introduced by the government. On 11 $1^{\text {th }}$ July 2019, Dasar Keusahawanan Negara 2030 has been launched that includes women entrepreneurs as the targeted group. Moreover, in the Malaysia budget 2021, the government has also introduced RM50 million budget specifically for women entrepreneurs, Ar Rahnu BizNita under Yayasan Pembangunan Ekonomi Islam Malaysia (YaPEIM). This incentive aims to empower women's entrepreneurship.

However, the main issues are these programmes may not reach the target group. Therefore, the implementation of the policy should be directed to women entrepreneur that needs the assistance provided by the government and other agencies. These assistances may be in 
terms of capital or finance, business advice, education, and training programmes. To empower women entrepreneurs require effective cooperation from all parties including the government and other agencies to ensure the inclusiveness of all entrepreneurs. Thus, there will be no issues of women entrepreneurs that were excluded from accessing all the information on assistance, training, and business opportunities.

Women have also endeavour themselves in the labour force to improve their family's economy. Their participation is not only as a worker but also as an entrepreneur. These women entrepreneurs play a vital role in the development of the country's economy. It is seen as important for growth, job creation, social, and economic development. Therefore, to ensure the success of Malaysia's economy, these women entrepreneurs must be taken care and the government and other agencies must ensure that all parts of the society will be included, supported, and enhanced.

\section{References}

Rahman, N. A., Yaacob, Z., Radzi, M. R. (2016). An Overview of Technological Innovation on SME Survival: A Conceptual Paper. Procedia - Social and Behavioral Sciences, 224, 508 515.

Abdul Mutalib, R., Arshad, R., Ismail, N. A., \& Ahmad, Z. (2015). Women and Entrepreneurship: An Overview of Women Entrepreneurship Programs in Malaysia. Special Issue on Social Entrepreneurship,11, 15-28.

Akehurst, G., Simarro, E., \& Mas-Tur, A. (2012). Women Entrepreneurship in Small Service Firms: Motivations, Barriers and Performance. Service Industries Journal, 32(15), 24892505. http://doi.org/10.1080/02642069.2012.677834

Al Mamun, A., Fazal, S. A., \& Muniady, R. (2019). Entrepreneurial Knowledge, Skills, Competencies and Performance: A study of Micro-enterprises in Kelantan, Malaysia. Asia Pacific Journal of Innovation and Entrepreneurship, 13(1), 29-48. https://doi.org/10.1108/APJIE-11-2018-0067

Ayob, N. A., Daud, S., \& Ismail. (2016). Faktor pembentukan modal insan dan daya saing usahawan wanita Malaysia: Kajian empirikal wanita bumiputera di Melaka. Geografia Online ${ }^{T M}$ Malaysian Journal of Society and Space, 12(5), $115-129$.

Bahramitash, R., \& Esfahani, H. S. (2014). Gender and Entrepreneurship in Iran. Middle East Critique, 23(3), 293-312. http://doi.org/10.1080/19436149.2014.949935

Bharthvajan, R. (2014). Women Entrepreneurs and Problems of Women Entrepreneurs. International Journal of Innovative Research in Science, Engineering and Technology. 3(9), 16104-16110. ISSN:2319-8753

Bhardwaj, B. R. (2014). Impact of education and training on performance of women entrepreneurs: A study in emerging market context. Journal of Entrepreneurship in Emerging Economies, ISSN: 2053-4604

Borg, A. (2013). Challenges facing Women Entrepreneurs. Retrieved from https://www.eurofound.europa.eu/observatories/eurwork/articles/challenges-facingwomen-entrepreneurs.

Bouazza, A. B., Ardjouman, D., \& Abada, O. (2015). Establishing the Factors Affecting the Growth of Small and Medium-sized Enterprises in Algeria. American International Journal of Social Science, Vol. 4, No. 2.

Chatterjee, S., Gupta, S. D., \& Upadhyay, P. (2020). Technology Adoption and Entrepreneurial Orientation for Rural Women: Evidence from India. Technological Forecasting and Social Change, Vol 160, 120236. 
Department of Statistics Malaysia. (2016). Labor Force Survey Report. Retrieved from https://www.dosm.gov.my/v1/index.php?r=column/pdfPrev\&id=SGZCNnMrWW9ZTE dpYys4YW0yRIhoQT09

Galli, E., \& Stefania, P. S. (2015). Bank Credit Access and Gender Discrimination: An Empirical Analysis. Retrieved from http://www.siecon.org/online/wpcontent/uploads/2015/10/Galli.pdf.

Hajwa, A., Rizki, M., Wan Hassin, W. S., \& Moi, W. S. (2017). Faktor-Faktor yang Mempengaruhi Kejayaan Usahawan Wanita Tekun: Satu Kajian di Daerah Hulu Langat. Proceeding of the 4th International Conference on Management and Muamalah 2017 (ICoMM 2017) e-ISBN: 978-967-2122-15-9

Haimid, M. T., Masdek, N. R. M., \& Rahim, H. (2016). Women Entrepreneurs in the Agriculture Sector: Issues and Challenges. Economic and Technology Management Review, 11, 5361.

Hashim, N. S. A., Yaakob, M. R., \& Muhayiddin, M. N. (2015). The Environmental Factors That Influence Success of Women Entrepreneurs: Entrepreneurial Intention as A Mediator. Retrieved from http://umkeprints.umk.edu.my/5047/1/Conference\%20Paper\%2040\%20\%20ISEB\%20 2015.pdf

Hassan, F., Ramli, A., \& Desa, M. N. (2014). Rural Women Entrepreneurs in Malaysia. What Drives Their Success. International Journal of Business and Management, 9(4).

Hassan, I. B., Mugambi, F. (2013). Determinants of Growth for Women Owned and Operated Micro Enterprise: The Case of Garissa, Kenya. International Journal of Business and Commerce, 2(7), 45-55.

Hassan, Z., Dollard, M. F., \& Winefield, A. H. (2010). Work-family Conflict in East VS Western Countries. Cross Cultural Management, 17(1), 30-49. http://doi.org/10.1108/13527601011016899

Khaleque, A. (2018). Performance of Women Entrepreneurs: Does Access to Finance Really Matter?. Eurasian Journal of Business and Economics, 11(21), 23-48.

Kumbhar, V. M. (2012). Some Critical Issues of Women Entrepreneurship in Rural India. SSRN Electronic Journal, (January 2012). http://doi.org/10.2139/ssrn.2043821

Lahiri, R. (2012). Problems And Prospects of Micro, Small and Medium Enterprises (MSMEs) In India in The Era Of Globalization. Semantic Scholar.

Loveline, A. A., Uchenna, O. I., \& Karubi, N. P. (2014). Women Entrepreneurship in Malaysia: An Empirical Assessment of The Challenges Faced by Micro and Small Business Owners in Kuching- Sarawak. International Journal of Humanities Social Sciences and Education (IJHSSE), 1(4), 48-58.

Mahmood, R., \& Hanafi, N. (2013). Entrepreneurial Orientation and Business Performance of Women-Owned Small and Medium Entreprises in Malaysia: Competitive Advantage as a Mediator. International Journal of Business and Social Sciences, 4(1).

Mohamad, M., \& Bakar, M. S. (2017). Malay Women Entrepreneurial Success: Challenges and Barriers. International Journal of Accounting, Finance and Business, 2 (5), 76-84.

Masuda, A. D., Sortheix, F. M., Beham, B., \& Naidoo, L. J. (2019). Cultural value orientations and work-family conflict: The mediating role of work and family demands. Journal of Vocational Behavior, Vol 112, 294-310.

Welch, M. (2021). Help wanted: Region Seeks to Fill Labor Shortage. The Winchester Star. Retrieved from https://www.winchesterstar.com/coronavirus/help-wanted-regionseeks-to-fill-labor-shortage/article_0a8b9b94-9dc8-59ac-b6e4-3f47ff50d559.html 
Mazlina, M., \& Punitha A/P S. (2016). Challenges and Success Factors of Female Entrepreneurs: Evidence from a Developing Country. International Review of Management and Marketing, 6(4):224-231.

Mohamad, M., Bakar, M. S. (2017). Malay Women Entrepreneurial Success: Challenges and Barriers. International Journal of Accounting, Finance and Business, 2(5), 76-84.

Musa, M., Shuib, R., Selamat, N., Isa, M. S., Osman, I., \& Abu Bakar, S. (2016). A Study of Women Micro Entrepreneurs in Malaysia: Livelihood Strategies And Challenges. In: $3 r d$ Kanita Postgraduate International Conference on Gender Studies, 16 - 17 November 2016, Universiti Sains Malaysia, Penang.

Mutalib, R. A., Arshad, R., Ismail, N. S., Ahmad, Z. (2015). Women and Entrepreneurship: An Overview of Women Entrepreneurship Programs in Malaysia. JGD Vol. 11, Special Issue on Social Entrepreneurship, 15-28.

Noraini, I. (2005). Dayasaing Usahawan Wanita dalam Era Ekonomi Global: Kajian Kes Wanita dalam Industri Makanan Halal. Seminar Keusahawanan Islam Peringkat Kebangsaan, APIUM: Kuala Lumpur.

OECD Report to G7 Leaders on Women and Entrepreneurship. (2017). Retrieved from https://www.oecd.org/gender/OECD-Report\%20-to-G7-Leaders-on-Women-andEntrepreneurship.pdf

Rashid, K. M., Ngah, C. H., Mohamed, Z., \& Mansor, N. (2015). Success Factors Among Women Entrepreneur in Malaysia. International Academic Research Journal of Business and Technology, 1(2), 28-36.

Samina, M. S. (2015). Women Entrepreneurs' Adoption and Use of Technology. Retrieved from https://www.cisco.com/c/dam/m/en_ca/offers/wec/pdfs/womenentrepreneurs-adoption-and-use-of-technology.pdf

Thuaibah, A. B., Azlah, M. A., Rozeyta, O., Hishamuddin, M. S., \& Noorizwan, S. M. (2007). Women's Involvement in Entrepreneurship in Johor: A Study About Critical Success Factors in Achievement and Failure in Handling Business. Project report, FPPSM: Universiti Teknologi Malaysia

Tundui, C., \& Tundui, H. (2012). Survival, Growth Strategies and Performance of Women Owned Micro and Small Businesses in Tanzania. International Journal of Business and Management, 7(8). 